\title{
Characterization of the Most Common Diseases in Children Under 5 Years (Pneumonia and Malnutrition): A Correlation Analysis.
}

\author{
Angélica Roca Pérez ${ }^{1}$, Anderson Díaz-Pérez ${ }^{2,3}$ \& Arley Vega Ochoa ${ }^{4}$ \\ ${ }^{1}$ Universidad Simón Bolívar, Facultad de Ciencias de la Salud, Barranquilla, Colombia \\ ${ }^{2}$ Universidad Simón Bolívar, Departamento de Ciencias Sociales y Humanas, Barranquilla, Colombia \\ ${ }^{3}$ Corporation Universitaria Rafael Núñez, Facultad de Ciencias de la Salud, Cartagena de Indias, Colombia \\ ${ }^{4}$ Universidad Popular del Cesar, Facultad de Ciencias de la Salud, Valledupar, Colombia \\ Correspondence: Angélica Roca Pérez, Universidad Simón Bolívar, Facultad de Ciencias de la Salud, Barranquilla, \\ Colombia. ID: ORCID. http://orcid.org/0000-0001-8035-0737 E-mail: aroca4@unisimonbolivar.edu.co
}

\author{
Received: May 30, 2018 Accepted: June 20, 2018 Online Published: July 11, 2018 \\ doi:10.5539/gjhs.v10n8p69 \\ URL: https://doi.org/10.5539/gjhs.v10n8p69
}

\begin{abstract}
Introduction: In Latin America the nutritional deficit is the most common problem affecting children under 5 years old, which is not an strange issue to Cartagena's population, this type of phenomenon is due to lack of nutritional education or food security that leads to appearance of infectious diseases such as pneumonia becoming a public health problem.
\end{abstract}

Objective: To correlate the clinical features of children with malnutrition, pneumonia and malnutrition, and pneumonia from Cartagena de Indias. 2010 to 2012.

Methodology: Retrospective cross-sectional descriptive-correlational study. 220 medical records from three groups were analyzed, including 98 children with malnutrition, 100 children with pneumonia and 22 children with malnutrition and pneumonia simultaneously medically attended during 2012-2014. Logistic regression was performed applying Pearson and Durbin Watson calculations with the software SPSS 20.0 ( .

Results: Male children have a higher prevalence of malnutrition and pneumonia simultaneously and separately by $63 \%$. The age with more pneumonia and malnutrition cases is in children under 2 years old from stratum I, likewise weight and respiratory problems correlate as common clinical features.

Conclusion: It is corroborated the existence of possible signs and symptoms common to pneumonia and malnutrition, in addition the design of dynamic programs that keep into account the environmental conditions.

Keywords: child malnutrition, pneumonia, nutritional status

\section{Introduction}

In Latin America, nutritional deficit is one of the problems that most affects children (Mujica-Coopman et al., 2015). The consequences of malnutrition in childhood are severe, which is related with the age of the child, especially during the first 5 years of life. The consequences range from a decrease in the IQ, learning problems, poor neurological development, reduced muscle development and frequent infectious diseases in childhood, to an increased risk of developing chronic diseases in adulthood and difficulties for social integration, which in general terms influences the quality of life and the economic performance of any population (Ramos-Martinez, González-Martínez, \& Luna-Ricardo, 2010). 30\% of the world population suffers from malnutrition and more than half of the 12 million annual deaths of children under 5 years old is related to this phenomenon (CEPAL \& UNICEF, 2006; Uribe Gil \& Alcaraz López, 2007). According to the National Survey performed by the ICBF-ENSIN about the Colombia Nutritional Situation, $46.1 \%$ of the child population presents food insecurity, this being understood as malnutrition problems and yearly $12 \%$ of five thousand children deceases in Colombia are due starvation problems (Álvarez-Uribe, Estrada-Restrepo, \& Fonseca-Centeno, 2010; CEPAL \& UNICEF, 2006; Martinez \& Díaz, 2010; Ocampo, Prada, \& Herrán, 2014; Viloria-de-la-Hoz, 2015). In Cartagena de Indias the chronic malnutrition rate in children under five years old due to inadequate nutrition is $12 \%$ (CEPAL \& UNICEF, 2006; González-Pastrana \& Díaz-Montes, 2015). Children suffering from malnutrition are more vulnerable to infectious diseases such as malaria, meningitis and pneumonia (Guamán, Valeria, Quizhpe Mora, \& 
Ordóñez Domínguez, 2015; Naranjo, Toapanta, \& Yumbay, 2011; Uribe Gil \& Alcaraz López, 2007; Villareyna López, 2015). The mortality rate for pneumonia in Cartagena city until 1993 was 16.2 per 100,000 inhabitants; after implementing the LRTI case management program, in 1994 the mortality rate dropped to $9.1 \times 100,000$ inhabitants, considering that the population under 5 years old in 1994 was 12.8 of the total population (León, Arrieta, Chacón, Igirio, \& Benguigui, 1998).

Acute respiratory infections represent an important cause of medical consultation at the primary and hospital care level (Sánchez, Marenco, Soler, \& Querol, 2007). Pneumonia among Acute Lower Respiratory Tract Infection (A.L.R.T.I.) continues to occupy one of the main causes of morbidity and mortality in children under 5 years of age in developing countries and represents between $80 \%$ and $90 \%$ of deaths due to A.L.R.T.I. They are among the first 5 causes of mortality in children under 5 years of age, causing worldwide 4.3 million deaths in children under 5 years of age, representing 30\% of total annual deaths (Delgado Romero et al., 2017; Guamán et al., 2015; Sillau, 2000). Malnutrition is considered as an important factor for children to have a depressed immune system (Delgado Romero et al., 2017; Fonseca, 2004; Pérez Sánchez et al., 2011; Rodríguez-Pecci et al., 2010). Furthermore when it is relates to the socioeconomic level, parents educational level, living conditions, such as overcrowding, environmental pollution and smoker family members, among other factors (Andrade \& Henríquez, 2010; Barnett et al., 2012; Prescott \& Vestbo, 1999). Respiratory infections are more prevalent in male children under 5 years of age and malnutrition prevails more in girls (Graham, 1990; Guamán et al., 2015; Morocho Barreto \& Portilla Rodas, 2012; Quiroga, 2012). It is considered as a hypothesis of the present study that malnutrition and pneumonia share common clinical characteristics likewise other authors consider it.

Objective. Correlate the clinical characteristics of children under 5 years old with malnutrition, pneumonia and malnutrition and pneumonia at the same time, seen at the Napoleón Franco Pareja Hospital. Cartagena de Indias. 2010 al 2012

\section{Method}

Retrospective cross-sectional descriptive-correlational study. The population consisted of initially analyzing 600 medical records of children who received medical attention at the Napoleón Franco Pareja Children's Hospital from January 2010 to December 2012. It was performed a probabilistic sampling with a confidence level of 95\% and a maximum error level of $6 \%$, for a total of 220 medical records that met the inclusion criteria. For the information analysis, the SPSS program version 20.0 was used. For descriptive analysis were calculated percentages and frequencies, for the correlational analysis was used the logistic regression, Pearson calculation (multifactorial) with a confidence level of $95 \%$ and a value of $p \leq 0.05$. Afterwards, the Durbin Watson test was performed to find a self-correlation between the data of the three groups of children (Malnutrition, Pneumonia and Malnutrition and Pneumonia at the same time).

\section{Results}

The most frequent age group was children under one (1) year old, the age of the study group was largely comprised for children of ages of 1 to 2 years (Mean $=1.5$ ). $60 \%$ of the children were from urban origin and $40 \%$ from the rural area of Cartagena city. Regarding sex, $62 \%$ of boys and $38 \%$ of girls presented pneumonia. Concerning the frequency of children with malnutrition, with malnutrition and pneumonia and children with only pneumonia it was found prevalence of $60 \%, 56 \%$ and $64 \%$ respectively, that is to say that boys presented with higher frequency this type of pathologies (Figure 1). 

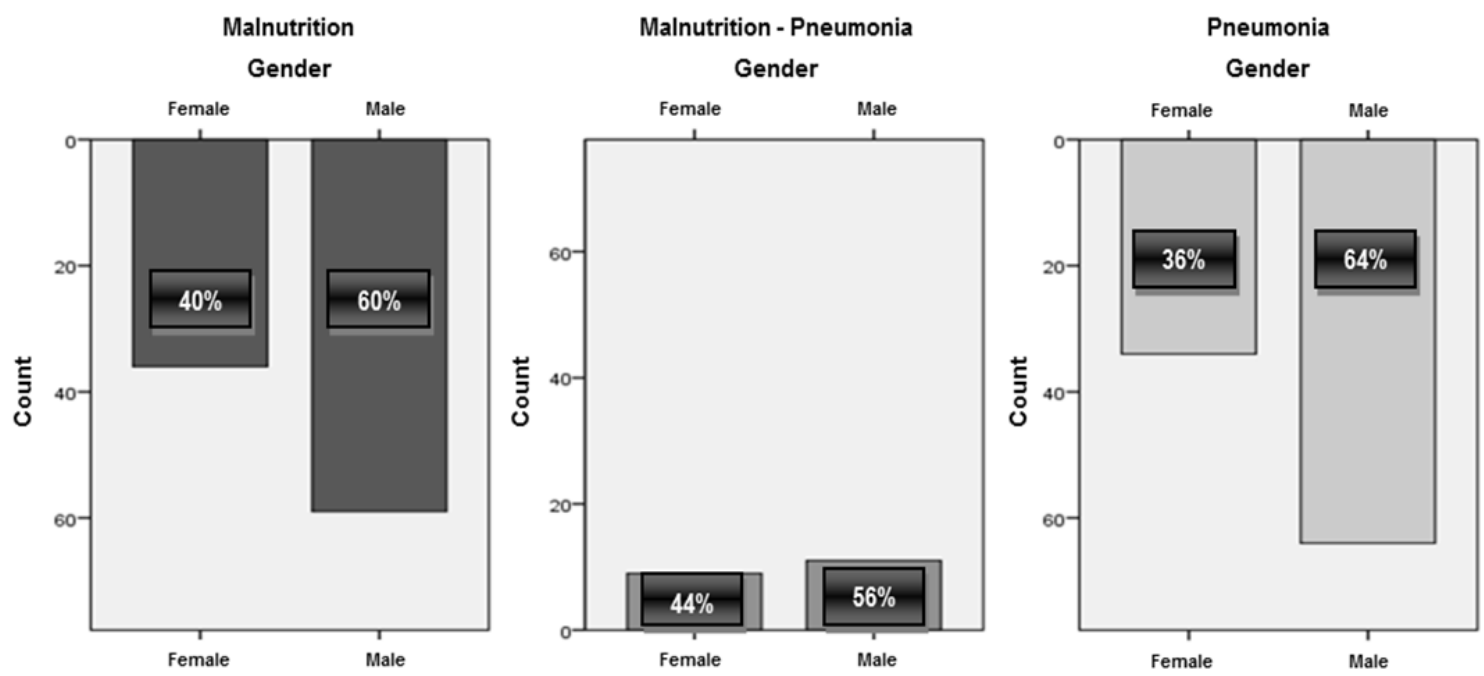

Figure 1. Children's sex and diagnosis (malnutrition, pneumonia and malnutrition and pneumonia at the same time)

It is observed that the age at what most children presented malnutrition symptoms is the first year of life; however, pneumonia was more likely to occur in the first two years of life with a tendency to present the pathology before the third year. Likewise, the likelihood to suffer from pneumonia and malnutrition is higher during the first year of life (Figure 2).
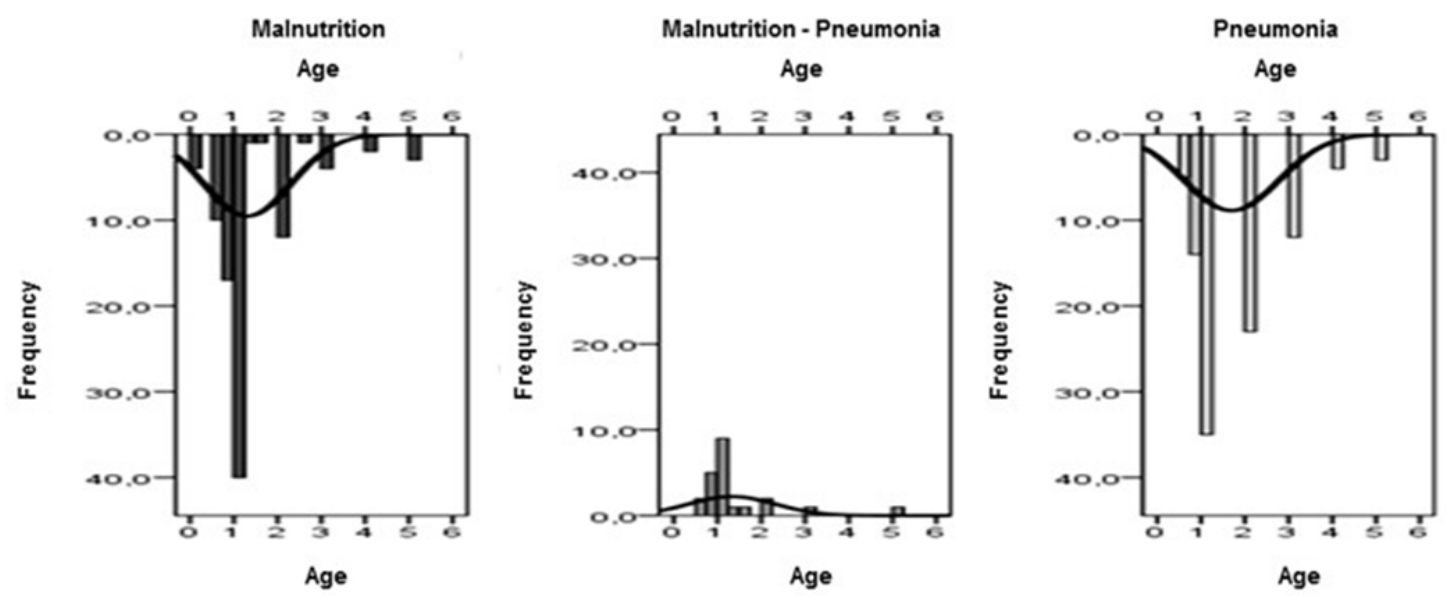

Figure 2. Age and performed diagnosis on children during first 5 years of life

Results show that the majority of children who have a tendency to malnutrition belong to the socioeconomic stratum one (I) where $90.3 \%, 83.7 \%$ and $95.2 \%$ presented malnutrition, pneumonia and malnutrition with pneumonia respectively (Table 1 ). 
Tabla 1. Special features of children according to the type of disease

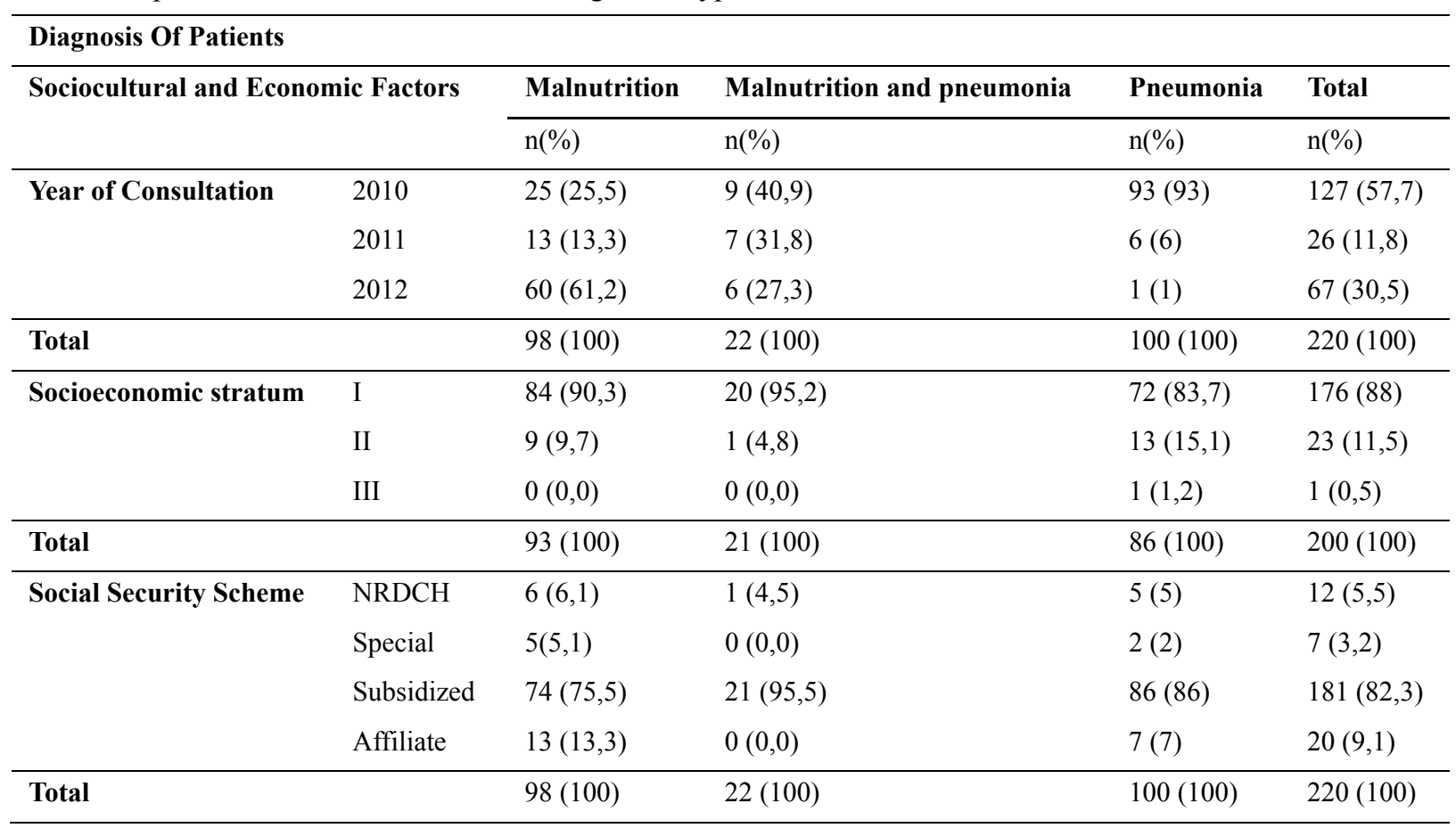

Nrdch: no reported data in the clinical history. n: number of children. \%: percentage.

The multivariate analysis between clinical signs and symptoms common in children with pneumonia, malnutrition and pneumonia with malnutrition, showed some common signs and symptoms among these as dyspnea $(\mathrm{r}=0.638$ $\mathrm{p} \leq 0.05)$; cough $(\mathrm{r}=0.633 \mathrm{p} \leq 0.05)$; expectoration $(\mathrm{r}=0.638 \mathrm{p} \leq 0.05)$; Indrawing of ribs $(\mathrm{r}=0.66 \mathrm{p} \leq 0.05)$; wheezing $(\mathrm{r}=0.63 \mathrm{p} \leq 0.05)$; rhoncus $(\mathrm{r}=0.638 \mathrm{p} \leq 0.05)$; tachypnea $(\mathrm{r}=0.641 \mathrm{p} \leq 0.05)$; vomiting $(\mathrm{r}=0.544 \mathrm{p} \leq 0.05)$ (Table 2$)$.

Table 2. Symptomatology and common signs presented in children with pneumonia, malnutrition and with malnutrition and pneumonia at the same time.

\begin{tabular}{|c|c|c|c|c|c|c|c|c|}
\hline \multirow[t]{2}{*}{ Symptoms } & & Malnutrition & $\begin{array}{l}\text { Malnutrition } \\
\text { Pneumonia }\end{array}$ & And & Pneumonia & Total & \multirow{2}{*}{$\begin{array}{l}\text { Coefficient Of } \\
\text { Contingency }\end{array}$} & \multirow{2}{*}{$\begin{array}{l}\mathrm{P} \leq \\
\mathbf{0 , 0 5}\end{array}$} \\
\hline & & $\mathrm{n}(\%)$ & $\mathrm{n}(\%)$ & & $\mathrm{n}(\%)$ & $\mathrm{n}(\%)$ & & \\
\hline \multirow{3}{*}{ Fiebre } & $\mathrm{NRDCH}$ & $53(54,1)$ & $7(31,8)$ & & $26(26)$ & $86(39,1)$ & \multirow{4}{*}{0,331} & \multirow{4}{*}{0,00} \\
\hline & No & $21(21,4)$ & $3(13,6)$ & & $14(14)$ & $38(17,3)$ & & \\
\hline & Yes & $24(24,5)$ & $12(54,5)$ & & $60(60)$ & $96(43,6)$ & & \\
\hline Total & & $98(100)$ & $22(100)$ & & $100(100)$ & $220(100)$ & & \\
\hline \multirow{3}{*}{$\begin{array}{l}\text { Weight } \\
\text { Changes }\end{array}$} & $\mathrm{NRDCH}$ & $53(54,1)$ & $7(31,8)$ & & $26(26)$ & $86(39,1)$ & \multirow{4}{*}{0,332} & \multirow{4}{*}{0,00} \\
\hline & No & $42(42,9)$ & $12(54,5)$ & & $73(73)$ & $127(57,7)$ & & \\
\hline & Yes & $3(3,1)$ & $3(13,6)$ & & $1(1)$ & $7(3,2)$ & & \\
\hline Total & & $98(100)$ & $22(100)$ & & $100(100)$ & $220(100)$ & & \\
\hline \multirow{3}{*}{$\begin{array}{l}\text { General } \\
\text { discomfort }\end{array}$} & $\mathrm{NRDCH}$ & $53(54,1)$ & $7(31,8)$ & & $26(26)$ & $86(39,1)$ & \multirow{4}{*}{0,309} & \multirow{4}{*}{0,00} \\
\hline & No & $37(37,8)$ & $15(68,2)$ & & $70(70)$ & $122(55,5)$ & & \\
\hline & Yes & $8(8,2)$ & $0(0,0)$ & & $4(4)$ & $12(5,5)$ & & \\
\hline Total & & $98(100)$ & $22(100)$ & & $100(100)$ & $220(100)$ & & \\
\hline
\end{tabular}




\begin{tabular}{|c|c|c|c|c|c|c|c|}
\hline \multirow{3}{*}{$\begin{array}{l}\text { Watery } \\
\text { rhinorrhea }\end{array}$} & $\mathrm{NRDCH}$ & $53(54,1)$ & $7(31,8)$ & $26(26)$ & $86(39,1)$ & \multirow{4}{*}{0,317} & \multirow{4}{*}{0,00} \\
\hline & No & $42(42,9)$ & $14(63,6)$ & $56(56)$ & $112(50,9)$ & & \\
\hline & Yes & $3(3,1)$ & $1(4,5)$ & $18(18)$ & $22(10)$ & & \\
\hline Total & & $98(100)$ & $22(100)$ & $100(100)$ & $220(100)$ & & \\
\hline \multirow{3}{*}{ Dyspnea } & $\mathrm{NRDCH}$ & $87(88,8)$ & $2(9,1)$ & $6(6)$ & $95(43,2)$ & \multirow{4}{*}{0,638} & \multirow{4}{*}{0,00} \\
\hline & No & $8(8,2)$ & $8(36,4)$ & $36(36)$ & $52(23,6)$ & & \\
\hline & Yes & $3(3,1)$ & $12(54,5)$ & $58(58)$ & $73(33,2)$ & & \\
\hline Total & & $98(100)$ & $22(100)$ & $100(100)$ & $220(100)$ & & \\
\hline \multirow{3}{*}{ Cough } & $\mathrm{NRDCH}$ & $87(88,8)$ & $2(9,1)$ & $7(7)$ & $96(43,6)$ & \multirow{4}{*}{0,633} & \multirow{4}{*}{0,00} \\
\hline & No & $4(4,1)$ & $4(18,2)$ & $26(26)$ & $34(15,5)$ & & \\
\hline & Yes & $7(7,1)$ & $16(72,7)$ & $67(67)$ & $90(40,9)$ & & \\
\hline Total & & $98(100)$ & $22(100)$ & $100(100)$ & $220(100)$ & & \\
\hline \multirow{3}{*}{ Expectoration } & $\mathrm{NRDCH}$ & $87(89)$ & $2(9,1)$ & $7(7)$ & $96(44)$ & \multirow{4}{*}{0,638} & \multirow{4}{*}{0,00} \\
\hline & No & $9(9)$ & $16(72,7)$ & $86(86)$ & $111(50)$ & & \\
\hline & Sí & $2(2)$ & $4(18,2)$ & $7(7)$ & $13(6)$ & & \\
\hline Total & & $98(100)$ & $22(100)$ & $100(100)$ & $220(100)$ & & \\
\hline \multirow{3}{*}{$\begin{array}{l}\text { Indrawing of } \\
\text { ribs }\end{array}$} & $\mathrm{NRDCH}$ & $87(89)$ & $2(9,1)$ & $8(8)$ & $97(44)$ & \multirow{4}{*}{0,66} & \multirow{4}{*}{0,00} \\
\hline & No & $8(8)$ & $3(13,6)$ & $59(59)$ & $70(32)$ & & \\
\hline & Sí & $3(3)$ & $17(77,3)$ & $33(33)$ & $53(24)$ & & \\
\hline Total & & $98(100)$ & $22(100)$ & $100(100)$ & $220(100)$ & & \\
\hline \multirow{3}{*}{ Wheezing } & $\mathrm{NRDCH}$ & 87 (89) & $2(9,1)$ & $8(8)$ & 97 (44) & \multirow{4}{*}{0,629} & \multirow{4}{*}{0,00} \\
\hline & No & $11(11)$ & $16(72,7)$ & $76(76)$ & $103(47)$ & & \\
\hline & Sí & $0(0,0)$ & $4(18,2)$ & $16(16)$ & $20(9)$ & & \\
\hline Total & & $98(100)$ & $22(100)$ & $100(100)$ & $220(100)$ & & \\
\hline \multirow{3}{*}{ Rhoncus } & $\mathrm{NRDCH}$ & $87(89)$ & $2(9,1)$ & $6(6)$ & $95(43)$ & \multirow{4}{*}{0,638} & \multirow{4}{*}{0,00} \\
\hline & No & $8(8)$ & $15(68,2)$ & $78(78)$ & $101(46)$ & & \\
\hline & Sí & $3(3)$ & $5(22,7)$ & $16(16)$ & $24(11)$ & & \\
\hline Total & & $98(100)$ & $22(100)$ & $100(100)$ & $220(100)$ & & \\
\hline \multirow{3}{*}{ Tachypnea } & $\mathrm{NRDCH}$ & 87 (89) & $2(9,1)$ & $6(6)$ & $95(43)$ & \multirow{4}{*}{0,641} & \multirow{4}{*}{0,00} \\
\hline & No & $11(11)$ & $16(72,7)$ & $85(85)$ & $112(51)$ & & \\
\hline & Sí & $0(0,0)$ & $4(18,2)$ & $9(9)$ & $13(6)$ & & \\
\hline Total & & $98(100)$ & $22(100)$ & $100(100)$ & $220(100)$ & & \\
\hline \multirow{3}{*}{ Vomiting } & $\mathrm{NRDCH}$ & $28(29)$ & $5(22,7)$ & $90(90)$ & $123(56)$ & \multirow{4}{*}{0,544} & \multirow{4}{*}{0,00} \\
\hline & No & $28(29)$ & $3(13,6)$ & $2(2)$ & $33(15)$ & & \\
\hline & Sí & $42(43)$ & $14(63,6)$ & $8(8)$ & 64 (29) & & \\
\hline Total & & $98(100)$ & $22(100)$ & $100(100)$ & $220(100)$ & & \\
\hline
\end{tabular}

Nrdch: no reported data in the clinical history. r: pearson's correlation coefficient. n: number of children. \%: percentage.

Some clinical characteristics were correlated, such as weight $(\mathrm{p}=0.0003)$ and respiratory distress $(\mathrm{p}=0.0149)$. In children with pneumonia, as with those who presented malnutrition, common signs were found, among these; the weight $(p=0.0000)$ and respiratory difficulty $(p=0.0000)$. In the analysis group of children with malnutrition and 
malnutrition-pneumonia, respiratory difficulty was correlated $(\mathrm{p}=0.0417)$ (Table 3$)$.

Table 3. Regression analysis for the three types of diagnosis present in patients according to symptoms or signs for pneumonia, malnutrition and pneumonia - malnutrition. ANOVA $(\mathrm{p} \leq 0,05)$

\begin{tabular}{|c|c|}
\hline $\begin{array}{l}\text { Regression Analysis For The Three Types Of Diagnosis Present In Patients According } \\
\text { To Symptoms Or Signs For Pneumonia, Malnutrition And Pneumonia - Malnutrition. }\end{array}$ & ANOVA $(p \leq 0,05)$ \\
\hline Weight $(\mathrm{Kg})$ & 0,0003 \\
\hline Heart Rate (Min) & 0,1861 \\
\hline Temperature $\left({ }^{\circ} \mathrm{C}\right)$ & 0,2584 \\
\hline Respiratory Difficulty & 0,0149 \\
\hline \multicolumn{2}{|l|}{ Linear Regression Analysis For Pneumonia With Malnutrition } \\
\hline Weight $(\mathrm{Kg})$ & 0,0000 \\
\hline Heart Rate (Min) & 0,8821 \\
\hline Temperature $\left({ }^{\circ} \mathrm{C}\right)$ & 0,3065 \\
\hline Respiratory Difficulty & 0,0000 \\
\hline \multicolumn{2}{|l|}{ Linear Regression Analysis For Pneumonia And Malnutrition - Pneumonia } \\
\hline Weight $(\mathrm{Kg})$ & 0,1184 \\
\hline Heart Rate (Min) & 0,1266 \\
\hline Temperature $\left({ }^{\circ} \mathrm{C}\right)$ & 0,4746 \\
\hline Respiratory Difficulty & 0,6772 \\
\hline \multicolumn{2}{|l|}{ Linear Regression Analysis For Malnutrition And Malnutrition - Pneumonia } \\
\hline Weight $(\mathrm{Kg})$ & 0,3000 \\
\hline Heart Rate (Min) & 0,1024 \\
\hline Temperature $\left({ }^{\circ} \mathrm{C}\right)$ & 0,6167 \\
\hline Respiratory Difficulty & 0,0417 \\
\hline
\end{tabular}

The Durbin-Watson test $p=0.0000$ for the whole group of variables; which indicates that there is a linear relationship between all signs and symptoms with the presence of pneumonia, malnutrition and children with malnutrition and pneumonia at the same time. n: Number of children. \%: Percentage

The correlation of clinical results demonstrated that children with pneumonia, malnutrition and with pneumonia and malnutrition together, they have comparable levels of neutrophil $(\mathrm{p}=0.026)$ and potassium $(\mathrm{p}=0.024)$. In children with pneumonia and malnutrition, it was found that have similar values total protein $(\mathrm{p}=0.0124)$ and oxygen saturation $(\mathrm{SaO} 2)(\mathrm{p}=0.0353)$ (Table 4$)$.

Regarding the group of children with pneumonia and malnutrition-pneumonia, lab results showed similar levels of lymphocyte $(\mathrm{p}=0.0093)$, neutrophils $(\mathrm{p}=0.0032)$, total protein concentration $(\mathrm{p}=0.0086)$ and potassium $(\mathrm{p}=0.0077)$; finally, the group of children with malnutrition and malnutrition-pneumonia, presented statistically similar leukocyte levels $(\mathrm{p}=0.0225)$ (Table 4$)$ 
Table 4. Correlation between results of laboratory tests for children with pneumonia, malnutrition and malnutrition and pneumonia at the same time.

\begin{tabular}{|c|c|c|c|c|}
\hline $\begin{array}{l}\text { Children With Pneumonia, } \\
\text { Pneumonia - Malnutrition }\end{array}$ & Malnutrition And & $P \leq 0,05$ & $\begin{array}{l}\text { Children With Pneumonia And } \\
\text { Malnutrition }\end{array}$ & $P \leq 0,05$ \\
\hline Erythrocytes & & 0,605 & Erythrocytes & 0,7238 \\
\hline Hemoglobin (g/dL) & & 0,827 & Hemoglobin $(\mathrm{g} / \mathrm{dL})$ & 0,5378 \\
\hline Leukocytes & & 0,150 & Leukocytes & 0,6173 \\
\hline Lymphocytes (\%) & & 0,114 & Lymphocytes (\%) & 0,7303 \\
\hline Neutrophils (\%) & & 0,026 & Neutrophils (\%) & 0,5647 \\
\hline Hematocrit (\%) & & 0,757 & Hematocrit (\%) & 0,9976 \\
\hline (VCM) & & 0,134 & $(\mathrm{VCM})$ & 0,2957 \\
\hline (HCM) & & 0,490 & $(\mathrm{HCM})$ & 0,3607 \\
\hline Platelet count & & 0,939 & Platelet count & 0,8792 \\
\hline VPM & & 0,742 & VPM & 0,3770 \\
\hline CHCM (g/dL) & & 0,638 & $\mathrm{CHCM}(\mathrm{g} / \mathrm{dL})$ & 0,9097 \\
\hline RDW (\%) & & 0,225 & RDW (\%) & 0,8218 \\
\hline Albumin (gr/dL) & & 0,172 & Albumin (gr/dL) & 0,5699 \\
\hline Globulin (gr/dL) & & 0,693 & Globulin (gr/dL) & 0,1908 \\
\hline Total proteins $(\mathrm{gr} / \mathrm{dL})$ & & 0,046 & Total proteins $(\mathrm{gr} / \mathrm{dL})$ & 0,0124 \\
\hline Potassium (mmol/L) & & 0,024 & Potassium (mmol/L) & 0,2332 \\
\hline Chlorine (mmol/L) & & 0,209 & Chlorine $(\mathrm{mmol} / \mathrm{L})$ & 0,5772 \\
\hline BUN & & 0,309 & BUN & 0,3303 \\
\hline Creatine & & 0,654 & Creatine & 0,0834 \\
\hline Urea & & 0,480 & Urea & 0,2062 \\
\hline$(\mathrm{SaO} 2)$ & & 0,769 & $(\mathrm{SaO} 2)$ & 0,0353 \\
\hline CRP 60,2 mg/dL) & & 0,909 & CRP $60,2 \mathrm{mg} / \mathrm{dL})$ & 0,4769 \\
\hline \multicolumn{3}{|c|}{ Children With Pneumonia And Malnutrition - Pneumonia } & \multicolumn{2}{|c|}{$\begin{array}{l}\text { Children With Malnutrition And Pneumonia - } \\
\text { Malnutrition }\end{array}$} \\
\hline Erythrocytes & & 0,5397 & Erythrocytes & 0,2930 \\
\hline Hemoglobin $(\mathrm{g} / \mathrm{dL})$ & & 0,7323 & Hemoglobin $(\mathrm{g} / \mathrm{dL})$ & 0,7836 \\
\hline Leukocytes & & 0,1865 & Leukocytes & 0,0225 \\
\hline Lymphocytes (\%) & & 0,0093 & Lymphocytes (\%) & 0,4606 \\
\hline Neutrophils (\%) & & 0,0032 & Neutrophils (\%) & 0,2512 \\
\hline Hematocrit (\%) & & 0,8508 & Hematocrit $(\%)$ & 0,5922 \\
\hline$(\mathrm{VCM})$ & & 0,6750 & $(\mathrm{VCM})$ & 0,2992 \\
\hline$(\mathrm{HCM})$ & & 0,7737 & $(\mathrm{HCM})$ & 0,8820 \\
\hline Platelet count & & 0,7941 & Platelet count & 0,6169 \\
\hline VPM & & 0,7507 & VPM & 0,9329 \\
\hline CHCM (g/dL) & & 0,5351 & $\mathrm{CHCM}(\mathrm{g} / \mathrm{dL})$ & 0,3186 \\
\hline RDW (\%) & & 0,1197 & RDW (\%) & 0,1607 \\
\hline Albumin (gr/dL) & & 0,2216 & Albumin (gr/dL) & 0,6202 \\
\hline Globulin (gr/dL) & & 0,9084 & Globulin (gr/dL) & 0,4482 \\
\hline Total proteins $(\mathrm{gr} / \mathrm{dL})$ & & 0,0086 & Total proteins $(\mathrm{gr} / \mathrm{dL})$ & 0,8598 \\
\hline Potassium (mmol/L) & & 0,0077 & Potassium $(\mathrm{mmol} / \mathrm{L})$ & 0,4189 \\
\hline Chlorine $(\mathrm{mmol} / \mathrm{L})$ & & 0,1189 & Chlorine $(\mathrm{mmol} / \mathrm{L})$ & 0,2804 \\
\hline
\end{tabular}




\begin{tabular}{llll}
\hline BUN & 0,6069 & BUN & 0,8371 \\
Creatine & 0,9183 & Creatine & 0,0844 \\
Urea & 0,6904 & Urea & 0,7843 \\
$(\mathrm{SaO} 2)$ & 0,1605 & $(\mathrm{SaO} 2)$ & 0,0766 \\
$\mathrm{CRP} 60,2 \mathrm{mg} / \mathrm{dL})$ & 0,4386 & $\mathrm{CRP} 60,2 \mathrm{mg} / \mathrm{dL})$ & 0,7785 \\
\hline
\end{tabular}

The Durbin-Watson $\mathrm{p}=0.0000$ for the whole group of variables; which indicates that there is a linear relationship between all the results of clinical laboratories in children with pneumonia, malnutrition and children with malnutrition and pneumonia at the same time. $n$ : Number of children. \%: Percentage

\section{Discussion}

It is clear that nutritional deficiency is associated with common diseases in children such as pneumonia, which becomes an underlying cause for the death of children under 5 years old. Malnutrition weakens the organism, which does not respond equally to the treatments when these children have pneumonia, this phenomenon is evidenced in the lower strata people as it is confirmed in the present study and others related to the subject (Álvarez Andrade, Rubén Quesada, \& Peña Coego, 2010). A high percentage of our population of study were under children under one year old, which suggests that a pneumonia infection associated with malnutrition leads to a poor prognosis of the infection presented as mentioned in studies conducted in Africa, Pakistan, Jordan and Bangladesh, among others (Baig-Ansari, Rahbar, Bhutta, \& Badruddin, 2006; Graham, 1990; Mian, Ali, Ferroni, \& Underwood, 2002; Seoty, Alam, Haque, \& Yasmin, 2015; Tekce \& Shorter, 1984). It was found that the highest prevalence are male children with low levels of nutrition, leading to a poor development of the innate immune system which leads to an inappropriate defense response, making the child susceptible to presenting infectious diseases such as pneumonia, since malnutrition thins the lungs membrane which facilitates the entry of bacteria and viruses (Pérez Sánchez et al., 2011).

Male children have a greater predisposition to infectious diseases than female, because men are more exposed to infections than women, making them less immunocompetent, according to the dynamic and evolutionary model proposed by Dr. Olivier Restif on the history of life which uses the disability immunocompetence hypothesis (Miller \& Cotter, 2017; Restif \& Amos, 2010; Rolff, 2002). To this analysis it is added that 22 analyzed children presented simultaneously malnutrition and pneumonia and their interaction leads to complications and more serious consequences than if they were presented in separately, which is demonstrated in the this research with a greater number of clinical results were correlated within the group of children affected simultaneously with pneumonia and malnutrition simultaneously. This behavior is mentioned in the literature and it is related to both respiratory and digestive infections that although not the subject of the present investigation, we found a relatively strong correlation with vomiting (Doan \& Bisharat, 1990; Mian et al., 2002; Sánchez et al., 2007; Seoty et al., 2015).

The environmental conditions synergistically influence the appearance of pneumonia and malnutrition, several studies show that climate change as well as causing natural disasters, also influences food insecurity and food contamination, making it a risk factor for developing child malnutrition and aggravate infectious diseases even if they are already present (Caldera, Escobar, \& Ortega, 2015; McMichael, Woodruff, \& Hales, 2006; Sheffield \& Landrigan, 2011). It was found that in 2010 there were a large number of children with pneumonia, possibly due the strong rainy season during this year (264 days of rain) in Bolívar department. Healthcare institutions should strive to provide food education campaigns to parents of children under 5 years old according to the cultural dynamics of the Cartagena's population, in addition to providing training about the signs and symptoms of Acute Lower Respiratory Tract Infection since the risk factors detection contribute to a better treatment by minimizing complications and mortality.

\section{Competing Interests Statement}

The authors declare that there are no competing or potential conflicts of interest.

\section{References}

Álvarez Andrade, M. E., Rubén Quesada, M., \& Peña Coego, A. (2010). Relación de aspectos clínicos y demográficos con la mortalidad en niños desnutridos ingresados en cuidados intensivos. Panorama Cuba y Salud, 5(3), 33-37

Álvarez-Uribe, M. C., Estrada-Restrepo, A., \& Fonseca-Centeno, Z. Y. (2010). Caracterización de los hogares 
colombianos en inseguridad alimentaria según calidad de vida. Revista de salud pública, 12(6), 877-888. https://doi.org/10.1590/S0124-00642010000600001

Andrade, J. E. O., \& Henríquez, M. A. O. (2010). Morbilidad en pacientes menores de cinco años con diagnóstico de enfermedad respiratoria y su relación con el nivel socioeconómico. Servicio de consulta externa, hospital del niño Dr."Francisco de Ycaza Bustamante". 2008 a 2009. Medicina, 15(3), 208-212.

Baig-Ansari, N., Rahbar, M. H., Bhutta, Z. A., \& Badruddin, S. H. (2006). Child's gender and household food insecurity are associated with stunting among young Pakistani children residing in urban squatter settlements. Food and Nutrition Bulletin, 27(2), 114-127. https://doi.org/10.1177/156482650602700203

Barnett, K., Mercer, S. W., Norbury, M., Watt, G., Wyke, S., \& Guthrie, B. (2012). Epidemiology of multimorbidity and implications for health care, research, and medical education: a cross-sectional study. The Lancet, 380(9836), 37-43. https://doi.org/10.1016/S0140-6736(12)60240-2

Caldera, S. V. N., Escobar, E. M. R., \& Ortega, V. E. (2015). Cambio climático como factor determinante de desnutrición en niños de 0-5 años de edad. CULCyT, (48).

CEPAL, N., \& UNICEF. (2006). Desnutrición infantil en América Latina y el Caribe.

Delgado Romero, A. K., Salazar Palechor, Y. M., Díaz, R., Eugenia Solano, V., Ruiz Beltrán, G., García Chaves, M. A., \& Calvache, J. A. (2017). Factores pronósticos de la infección respiratoria aguda baja grave en menores de 5 años en Colombia. Revista Ciencias de la Salud, 15(3), 313-324 https://doi.org/10.12804/revistas.urosario.edu.co/revsalud/a.6115

Doan, R. M., \& Bisharat, L. (1990). Female autonomy and child nutritional status: the extended-family residential unit in Amman, Jordan. Social Science \& Medicine, 31(7), 783-789. https://doi.org/10.1016/0277-9536(90)90173-P

Fonseca, J. C. (2004). Malaria, desnutrición y parasitosis intestinal en los niños colombianos: interrelaciones. Iatreia, 17(4), 354-369.

González-Pastrana, Y., \& Díaz-Montes, C. (2015). Características familiares relacionadas con el estado nutricional en escolares de la ciudad de Cartagena. Revista de Salud Pública, 17, 836-847. https://doi.org/10.15446/rsap.v17n6.43642

Graham, N. M. (1990). The epidemiology of acute respiratory infections in children and adults: a global perspective. Epidemiologic reviews, 12, 149-178. https://doi.org/10.1093/oxfordjournals.epirev.a036050

Guamán, Q., Valeria, I., Quizhpe Mora, P. L., \& Ordóñez Domínguez, M. F. (2015). Factores de riesgo en enfermedades respiratorias en niños/as menores de 5 años tomando como base la clasificación del AIEPI en el Subcentro de Salud Victoria del Portete. Cuenca. 2014 (B.S. thesis).

León, J. M., Arrieta, J. M. E., Chacón, E. P., Igirio, A. D., \& Benguigui, Y. (1998). Signos clínicos predictores de muerte en niños con neumonía, Hospital "Napoleón Franco Pareja", Cartagena, Colombia. Investigaciones operativas sobre el control de las infecciones respiratorias agudas (IRA) en niños en América Latina y el Caribe. Washington: Organizacion Panamericana de la Salud, 135-41.

Martinez, R. R., \& Díaz, F. A. E. (2010). Las enfermedades crónicas no transmisibles en Colombia. Boletín del observatorio en salud, 3(4), 1-9

McMichael, A. J., Woodruff, R. E., \& Hales, S. (2006). Climate change and human health: present and future risks. The Lancet, 367(9513), 859-869. https://doi.org/10.1016/S0140-6736(06)68079-3

Mian, R. M., Ali, M., Ferroni, P. A., \& Underwood, P. (2002). The nutritional status of school-aged children in an urban squatter settlement in Pakistan. Pakistan Journal of Nutrition, 1(3), 121-123. https://doi.org/10.3923/pjn.2002.121.123

Miller, C. V., \& Cotter, S. C. (2017). Pathogen and immune dynamics during maturation are explained by Bateman's Principle. Ecological Entomology, 42(S1), 28-38. https://doi.org/10.1111/een.12451

Morocho Barreto, M. A., \& Portilla Rodas, S. P. (2012). Factores de riesgo asociados a desnutrición en niños menores de cinco años, que acuden con sus madres al Centro de Salud N 1. Cuenca, 2012 (B.S. thesis).

Mujica-Coopman, M. F., Brito, A., López de Romaña, D., Ríos-Castillo, I., Cori, H., \& Olivares, M. (2015). Prevalence of anemia in Latin America and the Caribbean. Food and nutrition bulletin, 36(2_suppl), S119-S128. https://doi.org/10.1177/0379572115585775

Naranjo, G., Toapanta, M., \& Yumbay, D. (2011). Evaluación de la aplicación de la estrategia AIEPI en relación 
al tratamiento en el hogar de las infecciones respiratorias agudas (neumonías leves) niños menores de 5 años que acuden al Centro de Salud Gonzalo Cordero Crespo en el periodo de noviembre del 2010 a marzo del 2011. (B.S. thesis). Universidad Estatal de Bolívar. Facultad de Ciencias de la Salud y del Ser Humano. Escuela de Enfermería.

Ocampo, P. R., Prada, G. E., \& Herrán, O. F. (2014). Patrones de consumo alimentario y exceso de peso infantil; encuesta de la situación nutricional en Colombia, 2010. Revista chilena de nutrición, 41(4), 351-359. https://doi.org/10.4067/S0717-75182014000400002

Pérez Sánchez, M., Fundora Hernández, H., Notario Rodríguez, M., Rabaza Pérez, J., Hernández Sánchez, M. de los Á., \& Rodríguez Bertheau, A. (2011). Factores de riesgo inmunoepidemiológicos en niños con infecciones respiratorias recurrentes. Revista cubana de pediatría, 83(3), 225-235.

Prescott, E., \& Vestbo, J. (1999). Socioeconomic status and chronic obstructive pulmonary disease. Thorax, 54(8), 737-741. https://doi.org/10.1136/thx.54.8.737

Quiroga, E. F. (2012). Mortalidad por desnutrición en menores de cinco años, Colombia, 2003-2007. Biomédica, 32(4), 499-509 https://doi.org/10.7705/biomedica.v32i4.741

Ramos-Martinez, K., González-Martínez, F., \& Luna-Ricardo, L. (2010). Oral and nutritional health status in children attending a school in Cartagena, 2009. Revista de Salud Pública, 12(6), 950-960.

Restif, O., \& Amos, W. (2010). The evolution of sex-specific immune defences. Proceedings of the Royal Society of London B: Biological Sciences, rspb20100188. https://doi.org/10.1098/rspb.2010.0188

Rodríguez-Pecci, M. S., Carlson, D., Montero-Tinnirello, J., Parodi, R. L., Montero, A., \& Greca, A. A. (2010). Estado nutricional y mortalidad en neumonía de la comunidad. MEDICINA (Buenos Aires), 70(2), 120-126.

Rolff, J. (2002). Bateman's principle and immunity. Proceedings of the Royal Society of London B: Biological Sciences, 269(1493), 867-872. https://doi.org/10.1098/rspb.2002.1959

Sánchez, F. G., Marenco, A. S., Soler, J. L., \& Querol, M. S.-S. (2007). Características clínico-epidemiológicas de la neumonía adquirida en la comunidad en niños menores de 6 años. En Anales de Pediatría (Vol. 66, pp. 578-584). Elsevier. https://doi.org/10.1157/13107392

Seoty, N. R., Alam, M., Haque, R., \& Yasmin, N. (2015). Household food insufficiency and child nutritional status in urban slum, Dhaka, Bangladesh. Acta Medica International, 2(1), 65-69 https://doi.org/10.5530/ami.2015.1.10

Sheffield, P. E., \& Landrigan, P. J. (2011). Global climate change and children's health: threats and strategies for prevention. Environmental health perspectives, 119(3), 291. https://doi.org/10.1289/ehp.1002233

Sillau, J. (2000). Neumonías en niños menores de 5 años. Rev Enfer Tórax, 43(1), 39-42.

Tekce, B., \& Shorter, F. C. (1984). Determinants of child mortality: a study of squatter settlements in Jordan. Population and Development Review, 10, 257-280. https://doi.org/10.2307/2807964

Uribe Gil, G., \& Alcaraz López, G. (2007). El mal de ojo y su relación con el marasmo y kwashiorkor: El caso de las madres de Turbo, Antioquia, Colombia. Investigación y Educación en Enfermería, 25(2), 72-82

Villareyna López, J. (2015). Cumplimiento de la atención integral enfermedades prevalentes de la infancia, en el componente de neumonía en niños de 1 mes a 4 años egresados del Hospital Primario Carlos Centeno siuna, en el periodo de Marzo a Diciembre del año 2013 (PhD Thesis). Universidad Nacional Autónoma de Nicaragua, Managua.

Viloria-de-la-Hoz, J. (2015). Nutrición en el Caribe colombiano y su relación con el capital humano. Banco de la República de Colombia Documentos de Trabajo.

\section{Copyrights}

Copyright for this article is retained by the author(s), with first publication rights granted to the journal.

This is an open-access article distributed under the terms and conditions of the Creative Commons Attribution license (http://creativecommons.org/licenses/by/3.0/). 